University of Nebraska - Lincoln

DigitalCommons@University of Nebraska - Lincoln

6-2007

\title{
Emerging Positive Organizational Behavior
}

Fred Luthans

University of Nebraska - Lincoln, fluthans1@unl.edu

Carolyn M. Youssef

Bellevue University, carolyn.youssef@bellevue.edu

Follow this and additional works at: https://digitalcommons.unl.edu/leadershipfacpub

Part of the Management Sciences and Quantitative Methods Commons

Luthans, Fred and Youssef, Carolyn M., "Emerging Positive Organizational Behavior" (2007). Leadership Institute Faculty Publications. 8.

https://digitalcommons.unl.edu/leadershipfacpub/8

This Article is brought to you for free and open access by the Leadership Institute at DigitalCommons@University of Nebraska - Lincoln. It has been accepted for inclusion in Leadership Institute Faculty Publications by an authorized administrator of DigitalCommons@University of Nebraska - Lincoln. 


\title{
Emerging Positive Organizational Behavior
}

\author{
Fred Luthans \\ Department of Management, Gallup Leadership Institute, \\ University of Nebraska-Lincoln, Lincoln, NE 68588-0491 \\ Corresponding author: tel 402 472-2324, fax 402 472-5855, email fluthans@unl.edu
}

\author{
Carolyn M. Youssef \\ College of Business, Bellevue University, \\ 1000 Galvin Road South, Bellevue, NE 68005-3098
}

\begin{abstract}
Although the value of positivity has been assumed over the years, only recently has it become a major focus area for theory building, research, and application in psychology and now organizational behavior. This review article examines, in turn, selected representative positive traits (Big Five personality, core self-evaluations, and character strengths and virtues), positive state-like psychological resource capacities (efficacy, hope, optimism, resiliency, and psychological capital), positive organizations (drawn from positive organization scholarship), and positive behaviors (organizational citizenship and courageous principled action). This review concludes with recommendations for future research and effective application.
\end{abstract}

Keywords: positive organizational behavior, psychological capital, positive organizational scholarship, hope, efficacy, resilience, optimism

As positive psychology has gained momentum (e.g., Aspinwall \& Straudinger, 2003; Carr, 2004; Compton, 2005; Giacalone, Jurkiewicz, \& Dunn, 2005; Keyes \& Haidt, 2003; Linley \& Joseph, 2004; Lopez \& Snyder, 2003; C. Peterson, 2006; C. Peterson \& Seligman, 2004; Snyder \& Lopez, 2002; see also http://www.positivepsychology.org for a continually updated Web site on this body of knowledge), its implications for the workplace have not gone unnoticed. In particular, several identifiable domains and approaches to positivity in the workplace have recently emerged. These include positive organizational behavior (POB; e.g., see Luthans, 2002a, 2002b, 2003; Nelson \& Cooper 2007; T. A. Wright, 2003; Youssef \& Luthans, in press), positive organiza- 
tional scholarship (POS; Cameron \& Caza, 2004; Cameron, Dutton, \& Quinn, 2003; see http://www.bus.umich.edu/Positive/), and, more recently, psychological capital (PsyCap; see Luthans, Avey, \& Avolio, 2007; Luthans, Avey, Avolio, Norman, \& Combs, 2006; Luthans, Avolio, Avey, \& Norman, in press; Luthans, Avolio, Walumbwa, \& Li, 2005; Luthans, Luthans, \& Luthans, 2004; Luthans \& Youssef, 2004; Luthans, Youssef, \& Avolio, 2007a, 2007b; see http://www.gli.unl.edu for continual updates). There is a general consensus, even among the few dissenting voices (e.g., see Fineman, 2006), that the world in general, and our workplaces in particular, are in need of a more balanced approach that takes into consideration both the positive and the negative, both building on strengths and trying to correct weaknesses.

In this article, we review positivity in the workplace literature as it relates to organizational behavior, organizational leadership, and human resource management. Following Seligman and Csikszentmihalyi's (2000) initial conceptualization of positive psychology and Roberts's (2006) recent recommendations concerning the study of positivity in organizational behavior, our approach in structuring this review is to examine positive traits, positive state-like psychological resource capacities, positive organizations, and positive behaviors. Moreover, in line with Kilduff's (2006) recent proposed guidelines for analysis and review, we position the emerging stream of positivity-oriented theories and research as being complementary and an alternative perspective rather than as a substitute or replacement to the existing positively oriented and/or negatively oriented organizational behavior body of knowledge. Like positive psychology, the recently emerging POB does not proclaim to represent some new discovery of the importance of positivity but rather emphasizes the need for more focused theory building, research, and effective application of positive traits, states, organizations, and behaviors as represented in this review.

\section{Positivity: Why? Why Not?}

The workplace is increasingly becoming a place where survival, let alone success, necessitates higher-than-average performance (Avolio \& Luthans, 2006; Sutcliffe \& Vogus, 2003). Cutthroat competition and unhindered access to information, on a global scale, have created a world that is "flat" (Friedman, 2005). In flat-world competition, a sustainable edge can no longer be just achieved through raising entry barriers or technological breakthroughs. By the same token, success can also no longer be attained by just trying to fix weaknesses. In today's level playing field, success can be attained by "breaking the rules" (Buckingham \& Coffman, 1999) and challenging traditional assumptions and existing paradigms through appreciative inquiry (see Cooperrider \& Srivastva, 1987; Thatchenkery \& Metzker, 2006) of what is being done right and building on strengths.

Similar to a deficits approach, a positive perspective is far from being simple, straightforward, or risk free (for a comprehensive critique, see Fineman, 2006). For example, a positivity approach may promote a more benevolent view of humans than is truly warranted. This unfortunately was played out in the ethical meltdowns and the dark side of leadership that have recently plagued many of our former corporate icons. To focus only on what is positive may lead to at least implicitly attributing every vice and things that go wrong to the social context within which organizational behavior takes place. However, the social context is largely a creation of the individuals that make up that context and their interactions. In addition, what 
is considered positive (or negative) is to a great extent contingent on cultural values. Virtues in one culture may not hold true in another culture. Moreover, there seems to be more loss than gain from trying to separate the positive from the negative when they are so tightly entangled.

We would argue that much can be gained from utilizing approaches that help scholars and practitioners gain insights into both the positive strengths and the negative weaknesses and their interactions and limitations. As examples, overconfidence has been found to hinder subsequent performance (Vancouver, Thompson, Tischner, \& Putka, 2002; Vancouver, Thompson, \& Williams, 2001), unrealistic optimism can lead to evasion of responsibility (C. Peterson, 2000), and false hope can lead to poor allocation of resources and energies toward ineffective goals, to the detriment of both the individual and the organization (for other potential pitfalls in relation to the various positively oriented capacities, see Luthans, Youssef, et al., 2007a). As Seligman (2002) points out, the absence of psychopathology does not explain optimal functioning, excellence, growth, flourishing, and fulfillment. However, positively oriented human traits, states, organizations, and behaviors may have a substantial positive impact on performance and other desired outcomes beyond what material resources, classic business models, and deficit-oriented approaches can offer (Luthans, Youssef, et al., 2007a). In other words, positive approaches should not be refuted based only on what they may exclude (Roberts, 2006).

This review article, and positivity as a domain of inquiry, does not aim to discourage academic critical thinking or practical prudence. Today's organizations, and their participants, systems, resources, goals, and strategies, constitute positives to be celebrated and accelerated and negatives to be avoided, managed, or learned from. An integrative approach is necessary for a fuller understanding of the dynamics of success and failure in today's flat-world environment. We would argue that much is lost when either the positive or the negative is slighted or forgotten, and each in isolation of the other leaves much to be desired. With this framing of the role and perspective of positivity in the workplace serving as a point of departure, we now turn to a review of positive traits, state-like capacities, organizations, and behaviors.

\section{Positive Traits}

The role of enduring, relatively stable, positive traits in enhancing human performance in the workplace has been traditionally studied in the field of organizational behavior. For example, there is substantial support for the significant contribution of general mental ability to human performance across various domains, including the workplace (e.g., J. E. Hunter \& Hunter, 1984; Schmidt \& Hunter, 2000; Schmidt, Hunter, \& Pearlman, 1981). Intelligence is also positively related to leadership, although recent meta-analytic findings show that this relationship may be weaker than traditionally assumed (Judge, Colbert, \& Ilies, 2004). In this section, we focus on three more recently emerging research streams of positive traits, namely the Big Five personality traits, core self-evaluations, and positive psychological traits.

\section{The Big Five Personality Traits}

The Big Five personality traits of conscientiousness, emotional stability, extroversion, agreeableness, and openness to experience have been shown to strongly 
relate to performance (Barrick \& Mount, 1991). In addition, conscientiousness has been found to be the strongest and most generalizable predictor of these personality traits (Mount \& Barrick, 1995). The Big Five traits have been found to be related to individual-level outcomes such as happiness, physical and psychological health, spirituality, and identity; interpersonal-level outcomes such as quality of relationships with peers, family, and romantic others; and organizational- or sociallevel outcomes such as occupational choice, satisfaction, performance, community involvement, criminal activity, and political ideology (for a comprehensive review, see Ozer \& Benet-Martínez, 2006). These personality traits have also been found to be positively related to entrepreneurship (Zhao \& Seibert, 2006), cultural intelligence (Ang, Van Dyne, \& Koh, 2006), and satisfaction with teams (Peeters, Rutte, van Tuijl, \& Reymen, 2006) and negatively associated with undesirable outcomes such as burnout (Bakker, van der Zee, Lewig, \& Dollard, 2006).

Further contribution to the prediction of job performance beyond each of the global Big Five personality traits has recently been attributed to the "narrow traits" that constitute those traits (Dudley, Orvis, Lebiecki, \& Cortina, 2006). A recent promising trend in personality research has also been to study the interactions between the Big Five personality traits and more transient states or situational factors that can enhance or dampen their impact on various work-related outcomes (Ilies, Scott, \& Judge, 2006; G. L. Stewart \& Nandkeolyar, 2006).

\section{Core Self-Evaluations}

Another classification of positive traits that have an effect on work-related outcomes comes from Judge and colleagues' research on the four core self-evaluations of self-esteem, generalized self-efficacy, locus of control, and emotional stability. These traits, both independently and when combined into one higher order construct, have been shown to be significant positive predictors of goal setting, motivation, performance, job and life satisfaction, and other desirable outcomes (Erez \& Judge, 2001; Judge \& Bono, 2001; Judge, Bono, \& Locke, 2000; Judge, Locke, Durham, \& Kluger, 1998; Judge, Van Vianen, \& De Pater, 2004). In essence, the higher an individual's self-evaluations, the more positive the person's self-regard and the more goal self-concordance is expected to be experienced. Those with goal self-concordance are intrinsically motivated to pursue their goals for their intrinsic value. Because of the value congruence of the goals, they generate higher intrinsic motivation and trigger higher performance and satisfaction (Judge, Bono, Erez, \& Locke, 2005). Higher self-evaluations are also negatively associated with undesirable outcomes such as burnout (Best, Stapleton, \& Downey, 2005).

\section{Positive Psychological Traits}

More than ever before, as part of the positive psychology movement, the past several years have witnessed a substantial amount of research on positive psychological traits, enduring character strengths, and virtues and values that are held in the highest regard by many societies and cultures. Because of their stability and development over one's lifespan, rather than through brief interventions or onetime events, positive psychological traits can serve as a strong foundation for the 
development of more transient states. For example, although hope has been supported as being state like and thus open for development and improvement (Luthans, Youssef, et al., 2007a; Snyder et al., 1996), it also has a more stable trait-like baseline that can enhance or limit the level and range for one's state hope. Repeated initiatives to enhance state hope can in turn contribute to building trait hope over time and across situations (Snyder, 2000).

Several classification systems supported by theory, measurement, and research have recently emerged for systematically organizing the broad spectrum of positive psychological traits. For example, C. Peterson and Seligman (2004) classify 24 character strengths into six broad virtue categories. The first category is wisdom and knowledge, which includes the strengths of creativity, curiosity, open-mindedness, love of learning, and perspective. The second category is the virtue of courage, which includes the strengths of bravery, persistence, integrity, and vitality. The third category is the virtue of humanity and includes the traits of love, kindness, and social intelligence. The fourth category is the virtue of justice and includes the traits of citizenship, fairness, and leadership. The fifth category is the virtue of temperance and includes forgiveness and mercy, humility and modesty, prudence, and self-regulation. The sixth and final category is transcendence and includes the traits of appreciation of beauty and excellence, gratitude, hope, humor, and spirituality.

The focus of those who study character strengths is on reaching a consensual definition for each strength, tracking the theoretical traditions for its historical development, assessing its existing measures, taking inventory of its correlates and consequences, and outlining the factors and approaches that can contribute to its development or inhibition over the life span. Two of the primary criteria for character strengths are, first, that they should be trait like or stable over time and generalizable across situations and, second, that they should be valuable in their own right, not necessarily through the desirable outcomes they are capable of predicting or explaining (C. Peterson \& Seligman, 2004). Although the first of these two criteria may have some relevance to the workplace, especially in terms of selection, the second criterion may be viewed as less applicable in today's bottom line-oriented organizational culture.

Another classification system is offered by Snyder and Lopez (2002). They conceptualize and classify positive psychological approaches as emotion focused (e.g., subjective or psychological well-being, flow), cognitive focused (e.g., self-efficacy, goal setting, wisdom), self based (e.g., authenticity, humility), interpersonal (e.g., forgiveness, gratitude, empathy), biological (e.g., toughness), and coping approaches (e.g., humor, meditation, spirituality). This classification system is also in line with recent applications of positive psychology to the workplace (for a comprehensive review, see Luthans, Youssef, et al., 2007a).

C. Peterson and Seligman (2004) contend that, unlike a scientific taxonomy emphasizing an underlying structure based on established theory, a classification system better serves an emerging field such as positive psychology through establishing some working boundaries for its research and practice to develop and grow. Therefore, any classification system for positive psychological traits should not be viewed as fully comprehensive, exhaustive, or exclusive of others. We are in agreement with C. Peterson and Seligman's (2004) argument that the utilization of flexible classification systems is more relevant than that of rigid taxonomies given the current status of positivity research in general, not just in relation to positive psychological traits. Thus, the positive traits, states, organizations, and behaviors pre- 
sented in this review article, and in the supporting references cited throughout, should be thought of as serving as representative examples and anchor points rather than as exhaustive lists. Exploration of uncharted territories of untapped human potential is far from having been concluded.

\section{Positive State-Like Capacities}

Unlike positive traits, which are characterized by relative stability over time and applicable across situations, positive state-like capacities are relatively more malleable and thus are open to change and development (Luthans, 2002a, 2002b; Luthans, Youssef, et al., 2007a). This developmental characteristic of positive psychological resource capacities is particularly relevant to today's workplace, in which swiftness and flexibility in growth and development have to match the realities of a fast-paced, unpredictable environment. Consequently, positive psychological capacities open to investment and development (Luthans, Avey, et al., 2006; Luthans, Youssef, et al., 2007a, $2007 \mathrm{~b}$ ) may provide organizations with an unprecedented potential source of competitive advantage through their people. This newly recognized resource draws its competitive advantage from its potential for development and performance impact.

We have deliberately used the term state like when referring to positive capacities in POB to recognize they lie along a continuum with traits (Avolio \& Luthans, 2006; Luthans, 2002a, 2002b; Luthans et al., in press; Luthans, Youssef, et al., 2007a; Youssef \& Luthans, in press). Specifically, on one extreme of the continuum depicted by Luthans, Youssef, and colleagues (2007a) would be positive states that are very changeable representing momentary feelings (e.g., pleasure, positive moods, and many lay definitions of happiness). Next along the continuum would be the state-like positive psychological resource capacities that are still relatively malleable and open to development (e.g., efficacy, hope, optimism, and resilience).

These state-like capacities are followed on the continuum by the trait-like constructs that are relatively stable and difficult to change (e.g., Big Five personality dimensions, core self-evaluations, and character strengths and virtues). On the other extreme end of this continuum would be positive traits that are very stable, fixed, very difficult to change, and commonly referred to as being "hard wired" (e.g., intelligence, talents, and positive heritable characteristics). In other words, at least in the short run, the state-like psychological capacities may be somewhat stable and not change with each momentary situation, as would the more "pure" states such as positive moods. By the same token, however, the term state like also infers to being relatively less fixed than personality or self-evaluation traits.

The state-like positive psychological resource capacities are more malleable and thus open to change and development than are trait-like personality and self-evaluation constructs. Allied support for this conceptualization of being state like can be found in the research of Conley (1984). He found almost perfect test-retest correlations for recognized traits such as intelligence and personality, whereas self-opinions also revealed high test-retest correlation but still significantly lower than for the traits. In other words, the self-opinions were relatively less stable than the more fixed traits. There is also preliminary test-retest empirical evidence that the conscientiousness personality trait and core self-evaluation traits are relatively more stable across time than are the identified state-like psychological capacities of efficacy, hope, optimism, and resilience (Luthans et al., in press). 
To further support the proposed distinction between trait-like and state-like psychological constructs, a number of years ago George (1991) found positive mood as an affective state, but not the more stable trait of positive affectivity, to be predictive of both extra-role and in-role prosocial behaviors and sales performance 1 month later. She argued that although positive traits are predictive of more transient positive states, organizational behaviors tend to be spontaneous and interactively induced by both personality and situational factors. Indeed, recent research supports such interactive mechanisms (e.g., see Ilies et al., 2006), with positive states, but not necessarily positive traits, having significant main effects on performance and other desirable work-related outcomes. These empirical findings and others led T. A. Wright $(1997,2007)$ to introduce the importance of time as a main effect variable in organizational behavior research, with stability during 6 months as a proposed operationalization of the temporal demarcation between traits and states.

Recent conceptual theory building has also helped distinguish the trait-like versus state-like nature of traditionally recognized positive constructs. For example, contrasting various operationalizations of happiness, T. A. Wright (2005) makes the case for a trait-like measure of positive psychological well-being as more reflective of the happiness construct. He argues that this is especially true in relation to the happy worker-productive worker thesis, compared to other operationalizations, including (a) dispositional (trait-like) ones such as extraversion, emotional stability, positive affectivity, or negative affectivity; (b) transient ones (states) such as positive mood or lack of emotional exhaustion; and (c) highly contextualized ones such as job satisfaction. We now turn to a review of the POB resource capacities, which includes being state-like as one of the primary inclusion criteria.

\section{$P O B$}

Because POB is not the only positively oriented approach to organizational studies that has been stimulated and supported by positive psychology, it is important to identify its unique distinguishing characteristics. Luthans (2002b) first defined $\mathrm{POB}$ as "the study and application of positively oriented human resource strengths and psychological capacities that can be measured, developed, and effectively managed for performance improvement in today's workplace" (p. 59). More specifically, for a positive psychological capacity to qualify for inclusion in POB, it must be positive and must have extensive theory and research foundations and valid measures. Moreover, as described above, it must be state like, which would make it open to development and manageable for performance improvement. Finally, positive states that meet the POB definitional criteria are primarily researched, measured, developed, and managed at the individual, micro level (Luthans, 2002a, 2002b).

In its emphasis on theoretical grounding, valid measurement, and rigorous research, POB stands in stark contrast to the exponentially expanding body of popular best sellers, which share its positivity but lack theory, measurement, and empirical support. A notable exception is the Gallup Organization's research-based consulting practice and its steady stream of publications documenting the outcomes through measurement and research (Buckingham \& Clifton, 2001; Buckingham \& Coffman, 1999; Harter, Schmidt, \& Hayes, 2002). The state-like criterion distinguishes POB from other positive approaches that focus on positive traits (discussed 
previously), whereas its emphasis on micro, individual-level constructs separates it from positive perspectives that address positive organizations and their related macro-level variables and measures (discussed next under positive organizations). Meeting the inclusion criteria for POB are the state-like psychological resource capacities of self-efficacy, hope, optimism, and resiliency and, when combined, the underlying higher-order, core construct of PsyCap (Luthans, Youssef, et al., 2007a).

\section{Self-Efficacy as a State-Like Psychological Resource Capacity}

Building on Bandura's (1986, 1997, 2001) social cognitive theory and extensive empirical research, Stajkovic and Luthans (1998b) define self-efficacy in the workplace as "one's conviction (or confidence) about his or her abilities to mobilize the motivation, cognitive resources, and courses of action needed to successfully execute a specific task within a given context" (p. 66). Among the POB criteria-meeting capacities selected for inclusion, self-efficacy represents the best fit with all the criteria (Luthans, 2002a). Several factors are unique to self-efficacy and make it particularly relevant to POB.

First, self-efficacy has the most established theoretical foundation and the most extensive research support. Second, although hope, optimism, and resiliency have been conceptualized, measured, and tested both as traits and as states, self-efficacy has been primarily supported (Bandura, 1997) and measured (e.g., Maurer \& Pierce, 1998; Parker, 1998) as a state. Its state-like nature is manifested not only in its developmental nature over time but also in its domain specificity. Having efficacy in one domain is not necessarily transferable to other domains, whereas lacking efficacy in some contexts does not preclude being efficacious in others (Bandura, 1997).

Third, the relationship between self-efficacy and numerous work-related performance dimensions is highly established. These desirable outcomes include work attitudes across cultures (Luthans, Zhu, \& Avolio, 2006), leadership effectiveness (Chemers, Watson, \& May, 2000; Luthans, Luthans, Hodgetts, \& Luthans, 2001), moral or ethical decision making (May, Chan, Hodges, \& Avolio, 2003; Youssef \& Luthans, 2005a), creativity (Tierney \& Farmer, 2002), participation (Lam, Chen, \& Schaubroeck, 2002), career decision making (Nilsson, Schmidt, \& Meek, 2002), learning (Ramakrishna, 2002), and entrepreneurship (Boyd \& Vozikis, 1994; Chandler \& Jansen, 1997; C. C. Chen, Greene, \& Crick, 1998; Luthans \& Ibrayeva, 2006; Neck, Neck, Manz, \& Godwin, 1999). Meta-analytical findings (e.g., Bandura \& Locke, 2003; Stajkovic \& Luthans, 1998a) also support that self-efficacy is strongly related to work-related performance.

Often associated with confidence (e.g., Kanter, 2004; Stajkovic, 2006), self-efficacy is operationalized in terms of challenging self-set goals, self-selection into difficult tasks, self-motivation, generous effort investment and mobilization toward task mastery and goal accomplishment, and perseverance when faced with obstacles (Stajkovic \& Luthans, 1998a, 1998b). Such self-directed initiatives reflect proactive discrepancy creation, rather than reactive discrepancy reduction, which less-confident people may passively display as they respond to challenges that are imposed on them by their external environments. Consequently, less-efficacious individuals are more prone to failure, despair, and losing confidence when faced with negative feedback, social disapproval, obstacles and setbacks, or even 
self-created challenges such as self-doubt, skepticism, or negative perceptions and attributions (Bandura \& Locke, 2003).

On the other hand, confident individuals employ cognitive capacities such as symbolizing, forethought, observation, self-regulation, and self-reflection toward the accomplishment of their goals (Bandura, 1997; Stajkovic \& Luthans, 1998b). Symbolizing (e.g., creating mental pictures of products, processes, and outcomes that would be of interest to important stakeholders) can facilitate preparation for critical and challenging encounters. Forethought (e.g., anticipating proximal and distal milestones, accomplishments and potential obstacles) can enhance contingency planning, prioritization, and self-motivation when one takes a temporary emotional dive. Observation can facilitate learning from others, saving some of the time and energy involved in trial-and-error experiences. Self-regulation provides the initiative, proactiveness, and self-discipline necessary for confidence to materialize into actual productive behaviors that would lead to goal accomplishment, even when extrinsic motivators are lacking. Finally, self-reflection magnifies the positive impact of past experiences in terms of learning valuable lessons and applying them to future opportunities and challenges (for comprehensive descriptions, see Bandura, 1986, 1997, 2001; for practical examples of these cognitive processes, see Luthans, Youssef, et al., 2007a).

Self-efficacy, and its facilitating cognitive processes, can be developed and nurtured through mastery experiences, vicarious learning and modeling, social persuasion, and psychological and physiological arousal (Bandura, 1997, 2000; Maddux, 2002; Stajkovic \& Luthans, 1998a, 1998b). Mastery experiences can occur through on-the-job training and similar hands-on approaches, with tasks gradually increasing in their level of difficulty to allow for more frequent opportunities for practice and success. However, where actual experiences of success are risky, costly, or unavailable, self-efficacy can be developed through modeling and vicarious learning from others' successful experiences. Formal training programs, and informal approaches such as mentoring or coaching, are very effective for building efficacy, especially when the trainee can perceive similarities and relevance with the role model and when the observed task is as similar as possible to the actual tasks to be mastered.

In addition to mastery and vicarious experiences, social persuasion through positive feedback, group support and encouragement, respect, and trust can develop efficacy. This can directly occur through the impact of these positive social influences in creating a can-do attitude and indirectly occur through causing psychological arousal, which in turn would promote positive cognitions and emotions that can broaden one's range of possible actions and help build intellectual, physical, social, and psychological resources (Fredrickson, 2001, 2003b). Physical well-being, which can be accomplished through adequate work-life balance, preventive health care, diet and exercise, and psychological well-being and happiness, has been found to be related to productive work (Quick \& Quick, 2004; T. A. Wright, 2006; T. A. Wright \& Cropanzano, 2000, 2004) and also self-efficacy. Thus, the development of self-efficacy can take place in training interventions and programs (e.g., Luthans, Avey, et al., 2006; Luthans, Avey, et al., 2007) and through simple, informal factors such as a supportive organizational culture and even through the incremental accumulation of unplanned life events (Avolio \& Luthans, 2006; Luthans \& Avolio, 2003) and their impact on one's experiences, physical health, and psychological well-being. 


\section{Hope as a State-Like Psychological Resource Capacity}

Snyder, Irving, and Anderson (1991) define hope as "a positive motivational state that is based on an interactively derived sense of successful (1) agency (goaldirected energy) and (2) pathways (planning to meet goals)" (p. 287). Similar to selfefficacy, hope capitalizes on an individual's self-initiated, goal-directed motivations and behaviors. However, hope focuses on a different set of mechanisms through which goals are accomplished. One of these mechanisms or ingredients of hope is the sense of agency or internalized control that creates the determination and motivation (willpower) to accomplish one's goals.

A second component, unique to hope, is the process through which alternative pathways and contingency plans are created and adapted to achieve goals and overcome obstacles (way-power). Finally, hope involves the quality of goals being set and the mechanisms through which increasingly challenging goals are selected, approached, accomplished, and changed if necessary in light of additional evidence and new realities of the situation (Snyder, 1993, 1994, 1995a, 2000, 2002; Snyder, Ilardi, Michael, \& Cheavens, 2000; Snyder, Rand, \& Sigmon, 2002).

Critical to hope as a POB capacity is its state-like nature, which has been supported in its openness to development through recognized interventions. These interventions include goal-setting training, including stretch-goaling (setting challenging goals that are slightly beyond current reach), stepping (graduated mastery), and re-goaling to avoid false hope (Snyder, 2000). Organizational cultures and initiatives that also encourage participation, creativity, contingency planning, and "out-of-thebox" thinking can enhance their participants' hope, especially their pathways thinking. On the other hand, when resources are limited, pathways can be restricted as well. Resources include not only financial allocations but also authority, empowerment, information, communication channels, and trust (Luthans \& Jensen, 2002; Snyder, 1995a, 1995b; Snyder, Tran, et al., 2000; Veninga, 2000; Youssef \& Luthans, 2006; for a comprehensive review, see Youssef, Luthans et al., 2007a; for a highly focused micro-intervention strategy, see Luthans, Avey, et al., 2006). Valid and reliable measures of hope as a state have also been established (Snyder et al., 1996).

Finally, emerging research supports the relevance of hope to the workplace and its impact on performance outcomes. For example, recent empirical studies support a positive relationship between employee hope and performance and work attitudes (Youssef \& Luthans, in press) and organizational profitability (Adams et al., 2002), between entrepreneurs' hope and their satisfaction with business ownership (Jensen \& Luthans, 2002), between organizational leaders' hope and the profitability of their units and the satisfaction and retention of their employees (S. J. Peterson \& Luthans, 2003), and between Chinese factory workers' hope and their supervisor rated performance and merit salary (Luthans et al., 2005). More generally, hope has been found to relate to performance in various domains, including academic and athletic achievement, physical and mental health, survival and coping beliefs and skills, and other desirable positive life and well-being outcomes (Curry, Snyder, Cook, Ruby, \& Rehm, 1997; Kwon, 2000; Onwuegbuzie \& Snyder, 2000; Range \& Pentin, 1994; Scioli et al., 1997; Snyder, 2000). Theory building also continues to emerge regarding the performance impact of hope (Luthans, 2002a, 2002b; Luthans, Youssef, et al., 2007a; Luthans \& Youssef, 2004; Youssef \& Luthans, 2003) and its cross-cultural applications (Luthans et al., 2005; Luthans, Van Wyk, \& Walumbwa, 2004; Youssef \& Luthans, 2006). 


\section{Optimism as a State-Like Psychological Resource Capacity}

Most often associated with the work of Martin Seligman, the recognized pioneer of the positive psychology movement, optimism can be viewed as an attributional style that explains positive events through personal, permanent, and pervasive causes and negative events through external, temporary, and situation-specific ones. On the other hand, pessimism externalizes positive events and attributes them to temporary and situation-specific causes while internalizing negative events and attributing then to permanent and pervasive ones (C. Peterson \& Steen, 2002; Seligman, 1998). As a result of these attributional or explanatory style differences, optimists build positive expectancies that motivate their goal pursuit and approach coping behavior in the future, whereas pessimists are hindered by self-doubt and negative expectancies (Carver \& Scheier, 2002).

Similar to self-efficacy and hope, optimism is created, motivated, and developed in relation to the pursuit of personally valuable goals. However, optimism adds an external dimension to what self-efficacy and hope primarily explain through an internalized, agentic perspective (Bandura \& Locke, 2003; Snyder, Harris, et al., 1991). For example, the sources of an optimist's positive expectancies that promote a favorable view of the future may be the self, others, or external factors. Similarly, an optimist's interpretation of negative events primarily relies on externalizing and distancing himself or herself from failures. Moreover, unlike self-efficacy, which is domain specific, optimism utilizes generalized attributions, and unlike hope, optimism does not account for the pathways created and utilized for goal accomplishment (Luthans \& Jensen, 2002; Scheier \& Carver, 1985). In addition, although self-efficacy and hope are primarily cognitive in nature, optimism incorporates cognitive, emotional, and motivational components (C. Peterson, 2000; Seligman \& Csikszentmihalyi, 2000). Finally, the discriminant validity of self-efficacy, hope, and optimism has been supported through several empirical studies (Bryant \& Cvengros, 2004; Carifio \& Rhodes, 2002; Luthans et al., in press; Magaletta \& Oliver, 1999).

Optimism has been associated with a broad range of positive outcomes, including physical and psychological health, well-being, coping, and recovery (e.g., C. Peterson, 1999; Scheier \& Carver, 1987, 1992; Scheier et al., 1989; Seligman, 2002). On the other hand, pessimism has been related to various negative outcomes such as depression and physical illness (e.g., C. Peterson \& Seligman, 1984; C. Peterson, Seligman, \& Vaillant, 1988). However, the debate continues regarding the unidimensionality, bipolarity, or independence of optimism and pessimism (e.g., see Peterson \& Chang, 2002).

Particularly relevant to the inclusion of optimism in POB is its supported positive relationship with performance in various life domains (e.g., C. Peterson \& Barrett, 1987; Prola \& Stern, 1984), especially the workplace (Luthans et al., 2005; Luthans et al., in press; Seligman, 1998; Youssef \& Luthans, in press). For example, optimistic Metropolitan Life Insurance agents have significantly higher performance than do their more pessimistic counterparts (Seligman \& Schulman, 1986). Optimism has also been found to predict higher performance in sales, leadership, and others (e.g., Chemers et al., 2000; Schulman, 1999; Wunderley, Reddy, \& Dember, 1998).

Also integral to the POB inclusion criteria is the developmental nature of optimism. Similar to hope, optimism may have a dispositional baseline (Scheier \& 
Carver, 1987). However, in the same way that helplessness (a conceptual opposite of an optimistic explanatory style) can be learned, an optimistic explanatory style can also be learned and developed (Seligman, 1998) through focused interventions (Carver \& Scheier, 2002; Luthans, Avey, et al., 2006; Luthans, Avey, et al., 2007). A pessimistic explanatory style may develop over time because of either distorted or actual pessimistic attributions. These two types of pessimists can learn optimism in slightly different ways. For example, pessimists may habitually assume responsibility for unfavorable situations that are beyond their control or give credit to someone (or something) else for their own accomplishments. This type of pessimism can be refuted by identifying and challenging its underlying destructive assumptions and beliefs and replacing them with more positive and productive ones, which would result in a more realistic type of optimism (Schneider, 2001; Schulman, 1999). On the other hand, some people turn themselves into pessimists by setting unrealistic expectations and unattainable goals, thus positioning themselves where they would experience more failures than successes. This group can become more optimistic through learning more effective goal-setting strategies (Carver \& Scheier, 2002).

It is also important to note that optimism may not always be an effective explanatory style, and pessimism should not necessarily be negatively viewed. In situations that require prudence, contingency planning, preventive measures, and redundant systems, which are typical of many organizational settings, it is necessary for participants to be able to adapt their style, alternating between optimistic and pessimistic explanatory styles, or what is referred to as "flexible optimism" (C. Peterson, 2000; Schulman, 1999). Realistic, flexible optimism simultaneously allows recognition of positive achievements in oneself and others and accountability and acceptance of responsibility for challenges and difficult situations.

\section{Resiliency as a State-Like Psychological Resource Capacity}

Luthans (2002a) defines resiliency as "the capacity to rebound or bounce back from adversity, conflict, failure, or even positive events, progress, and increased responsibility" (p. 702). Unlike traditional conceptualizations of resiliency as an extraordinary capacity that can only be observed and admired in highly unique individuals, the positive psychology and $\mathrm{POB}$ perspective on resilience is that it is a learnable capacity that can be developed in the most ordinary of people (Masten, 2001; Masten \& Reed, 2002) and measured as state like (Luthans et al., in press; Wagnild \& Young, 1993).

Instead of only portraying resilient individuals as exceptional case studies of those who somehow defy the laws of gravity associated with adversity, Coutu (2002) describes them as those who accept reality, strongly hold onto meaningful and stable values and beliefs, and possess effective adaptive mechanisms that allow them to flexibly improvise in response to unexpected situations. Similarly, Wolin and Wolin (2006) challenge the "damage model" and its underlying "risk paradigm," which establish preconceived notions based on a person's "at-risk" classification. These labels, and consequently the ways in which the person is treated by mentors and peers, can become self-fulfilling prophecies that can set that person up for success or failure, independently of the person's real ability to cope, adapt, and bounce back. 
Despite its extensive theory building and applications in the clinical and developmental psychology literature (Block \& Kremen, 1996; Bonanno, 2004, 2005; Cowan, Cowan, \& Schulz, 1996; Huey \& Weisz, 1997; A. J. Hunter \& Chandler, 1999; Johnson et al., 1998; Kirby \& Fraser, 1997; Masten, 2001; Masten \& Reed, 2002; Richardson, 2002; Sandau-Beckler, Devall, \& de la Rosa, 2002; Smith \& Carlson, 1997; M. Stewart, Reid, \& Mangham, 1997), resiliency is just emerging in the management literature. As a POB capacity, resiliency draws from these rich theoretical and clinical research and practice foundations, extrapolating where common themes exist and adapting where warranted by the discontinuities across contextual differences.

For example, there are established approaches for developing resiliency that have been recently shown to be applicable to the workplace. Masten (2001; Masten \& Reed, 2002) outlines asset-focused strategies, risk-focused strategies, and process-focused strategies as effective approaches for building resiliency. Masten and Reed (2002) define an asset as "a measurable characteristic in a group of individuals or their situation that predicts a positive outcome in the future on a specific outcome criterion" (p. 76). Assets that are relevant to the workplace may include knowledge, skills, abilities, personality traits, and social relationships and support, all of which are predictive of higher performance. Asset-focused strategies emphasize building resiliency through enhancing one's asset inventories, thus increasing the probability of success.

On the other hand, risks or "vulnerability factors" (Kirby \& Fraser, 1997) are those that cause an "elevated probability of an undesirable outcome" (Masten \& Reed, 2002, p. 76). Work-related examples of risk factors may include stress, conflict, job insecurity, lack of communication and feedback, ineffective leadership, or counterproductive group dynamics. Risk-focused strategies decrease the probability of failure by eliminating or reducing as many risk factors as possible.

However, in line with the recognized developmental psychology literature (Egeland, Carlson, \& Sroufe, 1993), POB resiliency is primarily viewed as a process rather than an outcome. In this process, assets and risks are combined in a nonlinear fashion. Rather than focusing on the variety, frequency, and intensity of assets and risk factors that one possesses, the adaptive employment of assets to effectively deal with risk factors and the accumulation, interaction, and sequence of risks being faced and assets being created, developed, and deployed become the determining factors for the outcomes of the resiliency process (Sandau-Beckler et al., 2002). Process-focused strategies attempt to enhance resilience by building effective coping mechanisms that can facilitate the utilization of various assets to overcome adversity.

On the other hand, several additional perspectives and adaptations of the developmental psychology conceptualizations of resiliency have made it even more relevant and applicable to the workplace. For example, although Masten and Reed (2002) define resiliency as "a class of phenomena characterized by patterns of positive adaptation in the context of significant adversity or risk" (p. 75), the POB definition also takes into account the need to bounce back even from positive but potentially overwhelming events such as greatly increased responsibility and accountability. These challenges may be viewed as threats by those who lack resiliency but as challenging opportunities by those who possess considerable resiliency.

Moreover, the primary emphasis of the established clinical psychology applications of resiliency is bringing individuals back to their normal level of performance. On the other hand, in today's competitive workplace, progress from deficient to average performance is rarely sufficient (Sutcliffe \& Vogus, 2003). POB offers an ex- 
panded perspective on resiliency that incorporates "bouncing back and beyond" so that adversities and setbacks become opportunities for learning, development, and flourishing (Bonanno, 2004; Reivich \& Shatte, 2002; Ryff \& Singer, 2003), or what positive psychologists are investigating as "posttraumatic growth" (e.g., Tedeschi, Park, \& Calhoun, 1998).

In addition, although the possession of strong values and beliefs is critical for resiliency, these values and beliefs seem to take on different qualities and serve different functions in different contexts. For example, survival values may promote selfserving behaviors that may be critical in a military combat situation but that may not fit the needs and expectations for effective business leadership (Coutu, 2002). Values and beliefs draw their importance in building and sustaining resiliency from their stability over time. This is as applicable to organizations and their members as it is to individuals and groups in any other context (e.g., Weick, 1993). On the other hand, as a POB capacity, and also in line with the recent positive psychology conceptualizations of resiliency, the ethicality of those values has also been supported as an important dimension of resiliency (Avolio \& Luthans, 2006; Luthans \& Avolio, 2003; May et al., 2003; Richardson, 2002; Youssef \& Luthans, 2005a).

Given the additional perspectives that positive psychology and POB assimilate into resiliency, it becomes evident that resilience cannot be limited to just a reactive capacity that is expressed in times of adversity. POB resiliency also incorporates a proactive dimension that promotes discrepancy creation even in the absence of external threats (Bandura \& Locke, 2003). It allows adversities and setbacks to be viewed as opportunities for learning, growth, and development. It engages creative and flexible adaptive mechanisms, guided by ethical values and strong belief systems, toward the achievement of personally and organizationally meaningful goals. This type of resilience has been supported as a predictor of work-related outcomes and shown to be open to development and management in the workplace (Conner, 1993; Harland, Harrison, Jones, \& Reiter-Palmon, 2005; LaMarch, 1997; Luthans, Avey, et al., 2006; Luthans, Avey, et al., 2007; Luthans et al., 2005; Luthans et al., in press; Luthans, Vogelgesang, \& Lester, 2006; Reivich \& Shatte, 2002; Vickers \& Kouzmin, 2001; Waite \& Richardson, 2004; Waterman, Waterman, \& Collard, 1994; Zunz, 1998).

\section{Psychological Capital or PsyCap}

POB, with its criteria-meeting capacities of self-efficacy, hope, optimism, and resiliency, presents management researchers and practitioners with a high-potential source of competitive advantage to explore and on which to capitalize (Luthans, Youssef, et al., 2007a). However, recent preliminary and empirical findings across diverse samples support that these four positive psychological capacities may contribute more in combination and interaction in what is called PsyCap (Luthans et al., 2005; Luthans et al., in press). This PsyCap is comprehensively defined as

an individual's positive psychological state of development that is characterized by: (1) having confidence (self-efficacy) to take on and put in the necessary effort to succeed at challenging tasks; (2) making a positive attribution (optimism) about succeeding now and in the future; (3) persevering toward goals and, when necessary, redirecting paths to goals (hope) in order to succeed; and (4) when beset by problems and adversity, sustaining and bouncing back and even beyond (resiliency) to attain success (Luthans, Youssef, et al., 2007a, p. 3). 
Several sources of interactive synergy may exist when PsyCap is conceptualized, measured, and developed through this integrated framework.

First, when PsyCap is portrayed as a multidimensional, latent core construct (see Law, Wong \& Mobley, 1998), then it can draw from both within and across each psychological resource capacity. As a higher-order core factor, there is an underlying thread or commonality running through PsyCap that represents one's positive appraisal of the particular situation, the physical and personal resources available, and the probability of succeeding based on personal effort, upward striving, and perseverance (Luthans et al., in press). Allied support for this conceptualization of PsyCap as a higher-order core construct can be drawn from the psychological resource theories (see Hobfoll, 2002, for a comprehensive review). For example, multiple-component resource theories support build-out and contagion effects within the internal dimensions of constructs such as hope, efficacy, optimism, and/or resiliency (e.g., Antonovsky, 1979; Kobasa, 1979), whereas key resource theories also support interactive effects across such constructs (Cozzarelli, 1993; Rini, DunkelSchetter, Wadhwa, \& Sandman, 1999; Thoits, 1994).

Empirical support for PsyCap as a core construct is emerging through testing the convergent and discriminant validity of two or more of PsyCap's constituent psychological capacities (Bryant \& Cvengros, 2004; Carifio \& Rhodes, 2002; Magaletta \& Oliver, 1999) and specified models of PsyCap as a higher-order, core construct that underlies the four capacities that constitute it (Luthans et al., 2005; Luthans et al., in press). Such an approach is also consistent with the core self-evaluations model for four positive traits developed by Judge and colleagues (Judge \& Bono, 2001; Judge et al., 2005), the four dimensions that make up the core of transformational leadership (Avolio, Bass, \& Jung, 1999), and an empowerment core also comprised of four elements (Spreitzer, 1995).

Second, the contribution of PsyCap as a core construct is being conceptually supported by building out from the notions of traditional economic/financial capital and, more recent, human and social capital (Adler \& Kwon, 2002; Coleman, 1988; Luthans, Luthans, et al., 2004; Luthans \& Youssef, 2004; R. M. Wright \& Snell, 1999). Through this perspective, PsyCap is proposed to build-out and add value to what you already have (e.g., financial capital), what you know (human capital), who you know (social capital), and challenging and promoting the development of who you are today (the actual self) into what you can become in the future (the possible self). Preliminary research has found, at least as related to work attitudes, that PsyCap does add value to both human and social capital (Larson \& Luthans, 2006).

To date, a 24-item measure of PsyCap has been developed (Luthans, Youssef, et al., 2007a) and is being tested for its psychometric properties and nomological network for validity (Luthans et al., in press). In addition, a highly focused PsyCap development intervention has been designed and tested and was found to significantly increase managers' and employees' PsyCap levels in a variety of samples (Luthans, Avey, et al., 2006; Luthans, Youssef, et al., 2007a). Importantly, preliminary research also shows that PsyCap development interventions may have performance impact on the participants (Luthans, Avey, et al., 2007), and manipulating perceptions of leaders' PsyCap can result in other desirable outcomes such as increased trust and higher evaluations of leadership effectiveness (Norman, Avolio, \& Luthans, 2007).

Besides efficacy, hope, optimism, and resilience, several other high-potential positive psychological capacities have also been considered for inclusion in PsyCap 
(Luthans, Youssef, et al., 2007a). The inclusion criteria of being theory and research based, measurable, developmental, and manageable for performance impact in the workplace are again the primary determining factors for whether a specific positive capacity qualifies for potential inclusion in this version of POB and PsyCap. The cognitive capacities of creativity and wisdom, the affective capacities of subjective well-being, flow, and humor, and the higher-order capacity of authenticity seem to meet most of the PsyCap inclusion criteria (Luthans, Youssef, et al., 2007a). In addition, the more social positive capacities of gratitude, forgiveness, and emotional intelligence and the higher-order capacities of spirituality and courage are still being explored regarding their fit with the inclusion criteria (Luthans, Youssef, et al., 2007a). Similar to our previous discussion and how C. Peterson and Seligman (2004) treat their classification of characteristics and virtues in positive psychology, this categorization of $\mathrm{POB}$ and PsyCap is considered open for further development and inclusion of still other criteria-meeting positive capacities rather than being a closed taxonomy (Luthans, Youssef, et al., 2007a).

Finally, despite only emerging, PsyCap research already spans a variety of settings, contributing to its external validity. Specifically, preliminary research has found that PsyCap is related to performance and satisfaction in both high-tech manufacturing and service employee samples (e.g., Luthans et al., in press). Some cross-cultural PsyCap research has also taken place in China (Luthans et al., 2005), in addition to the efficacy component in Southeast Asia (Luthans, Zhu, et al., 2006) and Central Asia (Luthans \& Ibrayeva, 2006). Also, the implications for PsyCap have been analyzed with diverse populations such as immigrant entrepreneurs (Youssef \& Luthans, 2003), in addition to the hope component of organizational leaders in Africa (Luthans, Van Wyk, et al., 2004) and the Middle East (Youssef \& Luthans, 2006).

\section{Positive Organizations}

A positive approach to selection, development, and management of human resources in organizations has been emphasized by both scholars and professionals over the years. A wide variety of positively oriented high-performance work practices in placement, compensation, and motivation and their underlying strategies, structures, and cultures have also been extensively studied and supported for their contributions to organizational performance and competitiveness (e.g., Huselid, 1995; Pfeffer, 1998).

Research and consulting by the Gallup Organization also supports the importance of positive, strength-based organizational cultures and human resource practices (Buckingham \& Clifton, 2001; Buckingham \& Coffman, 1999; Wagner \& Harter, 2006). For example, factors such as effective selection and placement practices that capitalize on employees' talents, clear and aligned goals and expectations, social support and recognition, and opportunities for growth, development, and selfactualization have been found to significantly contribute to employee engagement, customer satisfaction, and ultimately organizational profitability and growth (Harter et al., 2002; Harter, Schmidt, \& Keyes, 2003).

On the academic side, the positive organizational scholarship or POS movement has been instrumental in providing macro-level scholars with a conceptual framework for organizing and integrating their research on positive organizations (Cameron et al., 2003). In this framework, POS is defined as 
the study of that which is positive, flourishing, and life-giving in organizations. Positive refers to the elevating processes and outcomes in organizations. Organizational refers to the interpersonal and structural dynamics activated in and through organizations, specifically taking into account the context in which positive phenomena occur. Scholarship refers to the scientific, theoretically derived, and rigorous investigation of that which is positive in organizational settings (Cameron \& Caza, 2004, p. 731).

Thus, as seen in this definition, POS is in line with other positive approaches such as positive psychology, $\mathrm{POB}$, and PsyCap in its positivity and scientific rigor but is distinguished from these other positive approaches in its more organization-level orientation. Also unique to POS is its utilization of diverse qualitative and quantitative research methodologies. Similar to POB and PsyCap, but different from positive psychology, the primary emphasis of POS is the workplace and the accomplishment of work-related outcomes.

Several characteristics of positive organizations stem from the positivity of the participants (i.e., their traits, states, and/or behaviors). However, a group of positive individuals may not necessarily add up to a positive team, operating unit, or organization. For example, Kanov et al. (2004) argue that although organizational compassion shares many of the characteristics of individual compassion, including noticing, feeling, and responding to the pain of others, in organizational compassion these processes become collective in nature. These collective cognitions, emotions, and actions are legitimated, promoted, and coordinated by factors (e.g., values, norms, policies, and practices) that exist in the organizational context in which they take place. These collective cognitions and factors cause them to be manifested in ways that are different from isolated incidents of individual compassion (Kanov et al., 2004).

Parallel distinctions can be made between several seemingly similar organizational- and individual-level constructs. For example, organizational virtuousness can facilitate, enable, and even engender individual level virtuousness. This is accomplished through factors beyond the individual members' actions, to include "collective activities, cultural attributes, or processes that enable dissemination and perpetuation of virtuousness in an organization" (Cameron, Bright, \& Caza, 2004, p. 768). Importantly, this virtuousness has been found to relate to organizational performance (Cameron et al., 2004). Likewise, organizational resiliency may be promoted through organizational-level asset-focused strategies, risk-focused strategies, process-focused strategies, and values that can meaningfully guide and trickle down to enhance unit and individual resiliency (Youssef \& Luthans, 2005b). A humanistic work ideology, including compassion, virtuousness, resiliency, and other similar positive characteristics, can equip organizations with the dynamic capabilities necessary for adaptability and responsiveness to environmental changes using strategies that would add value through human capital (Wooten \& Crane, 2004).

To further elaborate on the contributions of positive organizations being beyond those of their individual members, collective efficacy can be used as a case in point. Unlike self-efficacy, collective efficacy does not necessitate perceptions and beliefs of personal mastery for a given task and context but rather the "group's shared belief in its conjoint capabilities to organize and execute the courses of action required to produce given levels of attainments" (Bandura, 1997, p.477). The integrated team is the referent for such collective efficacy. Thus, it is becoming evident that in today's work environment, characterized by interdependence and teamwork, posi- 
tive organizations are critical in building the necessary context for positive traits to be selected, for positive states to be developed and managed, and for positive behaviors to be exhibited, recognized, and promoted. We now give attention to these positive behaviors.

\section{Resultant Positive Behaviors}

Given the competitiveness of today's environment, it is essential for the impact of positive traits, states, and organizations to manifest themselves in terms of tangible, measurable behaviors that can have direct performance impact. In this final section, we review several representative emerging types of positive behaviors that can be predicted and explained by actual and potential intersections between positive individual traits and states and positive organizational characteristics. Many of these positive behaviors can be grouped under the umbrella of "positive deviance," which Spreitzer and Sonenshein (2004) define through a normative approach as "intentional behaviors that depart from the norms of a referent group in honorable ways" (p. 832). Related to although somewhat distinct from this construct of positive deviance are representative positive behaviors such as organizational citizenship behavior (OCB) and courageous principled action.

OCB can be defined as "individual behavior that is discretionary, not directly or explicitly recognized by the formal reward system, and that in the aggregate promotes the effective functioning of the organization" (Organ, 1988, p. 4). Dimensions of OCB include altruism, conscientiousness, civic virtue, sportsmanship, and courtesy (Brief \& Motowidlo, 1986; Podsakoff, MacKenzie, Moorman, \& Fetter, 1990; for a critical meta-analytical review, see also LePine, Erez, \& Johnson, 2002). OCB can be predicted through positive personality traits, positive attitudes, and motivation (Organ \& Ryan, 1995) and positive institutional characteristics such as organizational support and procedural justice (Moorman, Blakely, \& Niehoff, 1998). Recent empirical studies support the interaction between individual-level positive personality traits and states in predicting both the frequency and consistency of engaging in OCBs (Ilies et al., 2006).

Courageous principled action occurs "when people must draw upon their intuitive, emotional, interpersonal, and cognitive resources in order to undertake actions in line with the highest goals of the organization but not part of the accepted routine or status quo" (Worline \& Quinn, 2003, p. 145). In addition to the contributions of individual traits and states, various organizational factors such as the form or design have been proposed as enablers or constraints of courageous principled action. For example, the dominant values and emphasis of organizations in market economies on ambition, competition, efficiency, and initiative may necessitate courageous principled action that challenges the status quo by promoting values such as loyalty, trust, honesty, and integrity. Whistle-blowing is an example of courageous principled action that seeks the organization's long-term interests of maintaining a positive reputation but that may challenge the organization's status quo in the short-run, exposing the courageous actor to many immediate risks such as social disapproval or job loss (Miceli \& Near, 2005).

In addition to specific resultant behaviors such as OCBs and courageous principled actions, several mechanisms through which positivity can affect observable behaviors have also been recently proposed. For example, in Fredrickson's 
(2001) broaden-and-build model, positive emotions help build intellectual, physical, social, and psychological resources. Especially the psychological resources can expand one's potential courses of action and help build a cushion and buffering mechanisms that can facilitate resilient bouncing back in times of adversity and when negative emotions are experienced in the future. In addition, positive emotions can exhibit upward spirals, contagion effects, and individual-organizational exchanges. This positivity has been found to expand these effects beyond the individual level to the group and organizational levels and the behavioral intentions and activated instrumental behaviors that result (Bagozzi, 2003; Fredrickson, 2003a).

Recent empirical studies also support this increasing contribution of positivity to desirable work-related outcomes. For example, using Fredrickson's broaden-andbuild model, T. A. Wright, Cropanzano, and Bonett (in press) found that psychological well-being moderates the relation between job satisfaction and job performance. This finding may account for the inconsistent results of previous studies solely focusing on the job satisfaction-job performance relationship to explain the happyproductive worker thesis. More specifically, job performance was highest when employees reported high scores on both psychological well-being and job satisfaction. In another study, based on Hobfoll's (2002) conservation of resources model, management personnel were found to be most likely to turn over when both their psychological well-being and their job satisfaction were low (T. A. Wright \& Bonett, in press), providing further support for the nonadditive contribution of those two factors to work-related outcomes.

Similarly, in the emerging authentic leadership development literature, authentic leaders are developed through the concerted contributions of life experiences and stable personality traits, positive psychological states, and a supportive, developmental organizational climate. Authentic leaders in turn engage in behaviors that build their associates' authentic leadership and followership capacities and that are transparent, moral, ethical, and future oriented (Avolio \& Luthans, 2006; Gardner, Avolio, Luthans, May, \& Walumbwa, 2005; Luthans \& Avolio, 2003; Luthans, Norman, \& Hughes, 2006; May et al., 2003). For example, authentic leaders' self-transcendent values, positive cognitions, and positive other-directed emotion may interactively promote positive, self-transcendent organizational behaviors. This perspective stands in stark contrast to traditional negative views of emotions in leadership as manipulative or counterproductive (Michie \& Gooty, 2005). However, a leader's authenticity and ability to exhibit self-transcendent behaviors are also deeply rooted in self-awareness, person-role congruence, and self-concordant goals and the ability to authentically articulate such a perspective in ways that are inspiring and constructive to oneself and others (Shamir \& Eilam, 2005; Sparrowe, 2005). In other words, authentic leadership and its development can offer another untapped positive resource that can result in upward spirals of positive change across various organizational levels.

\section{Conclusions and Future Directions}

As reflected in the title of this review article, the current status of the theory, research, and practice of POB is still emerging. However, as indicated, significant progress is being made. As with any new domain of inquiry, only through further theory 
building and research can POB be better understood and fully utilized for performance impact. In our concluding comments, we propose a roadmap for further progress in the journey of better understanding and effective application of POB.

First, as discussed at different points throughout this review article, an integrated theoretical framework, along with a comprehensive, but open, classification of positive traits, state-like capacities, organizations, and behaviors should be the ultimate goal. This comprehensive approach necessitates studies that concurrently test the relative contributions of each of those influences and the interactions among them (e.g., see G. Chen, Gully, Whiteman, \& Kilcullen, 2000; Ilies et al., 2006). This proposed positivity framework would also require the investigation, application, and integration of nontraditional or understudied positive psychological capacities and a multidisciplinary approach to draw from the relevant literature in other fields of study. This suggestion could follow the approach adopted in POB, POS, and PsyCap in relation to resiliency (Youssef \& Luthans, 2005b). Including the characteristics of positive organizations in such a framework would also pose challenges that are common to multilevel research, such as small sample sizes, methodological complexities, and rater-induced biases (e.g., see Klein \& Kozlowski, 2000; LeBreton, James, \& Lindell, 2005).

Second, because valid and reliable measurement represents the core and prerequisite of scientific inquiry, it is necessary to continually refine existing measures of positive constructs, and to develop others that are specific and valid for the workplace. Our recently developed 24-item PsyCap Questionnaire may serve as an example for such measurement (Luthans, Youssef, et al., 2007a; Luthans et al., in press). However, as more positive capacities are added to PsyCap, and as the integrated perspective described above is developed over time, more comprehensive and elaborate measures will be necessary. These measures may also need to integrate both quantitative and qualitative methodologies to capture some of the promising constructs and mechanisms that may be difficult to assess through traditional survey measures.

Third, the external validity of POB constructs should be tested in a wide variety of settings. Comparisons can facilitate extrapolations from existing findings and further understanding of these positive constructs' contextual applicability and situational limitations. For example, PsyCap constructs have been found applicable in cross-cultural (Luthans et al., 2005; Luthans \& Ibrayeva, 2006; Luthans, Zhu, et al., 2006) and entrepreneurial settings (Jensen \& Luthans, 2006; Luthans \& Ibrayeva, 2006). To date, many questions remain unanswered regarding the applicability of POB to other contexts such as organizations of various sizes, in a variety of industries, and in virtual business environments.

Fourth, positivity researchers and practitioners should not take for granted the common but often mistaken assumption that related positive and negative constructs are extreme ends of a continuum. For example, C. Peterson and Chang (2002) argue against the linear unidimensionality of optimism and pessimism despite their negative correlation. They contend that to assert whether optimism and pessimism are unidimensional, bipolar, or independent, more comprehensive studies are needed, in which a wider range of positive and negative outcomes can be investigated. Similarly, Lee and Allen (2002) report only a moderate negative correlation between $\mathrm{OCB}$ and negative deviance. A more comprehensive approach is needed. Specifically, both positive and negative constructs and their broad spectrum of outcomes need to be studied. This can result not only in a broader perspec- 
tive and better understanding of various positive constructs but also may facilitate the development and refinement of their measures and uncover potential nonlinear and interactive mechanisms.

Finally, a challenge that faces not only positivity research but also organizational behavior research in general is the accurate, objective and comprehensive measurement of performance and performance change (Dess \& Robinson, 1984). Several approaches have been suggested to help overcome this challenge, the most common of which is integrating a broader range of performance-related attitudinal outcomes (Chakravarthy, 1986). This broadening with attitudinal outcomes has been supported as a more effective approach to holistically capture overall performance and effectiveness (Harter et al., 2002; Harter et al., 2003), and its relevance to positivity research has been recently highlighted (Roberts, 2006; Youssef \& Luthans, in press). Others have suggested incorporating a variety of subjective, self-reported, and other-reported measures, with varying degrees of success (for a comprehensive review of potential problems and remedies for this approach, see Podsakoff, MacKenzie, Lee, \& Podsakoff, 2003). This performance measurement challenge is far from being resolved. Creativity and comprehensiveness in collecting and integrating multiple measures should help bring researchers closer to accurately and validly measuring a variety of outcomes of interest in organizational behavior in general and positive research in particular.

In total, the POB journey does seem to be off to a good start. The vision of the destination of unique competitive advantage through people seems worth a long and arduous trip through more theory building, research, and effective application.

\section{References}

Adams, V. H., Snyder, C. R., Rand, K. L., King, E. A., Sigmon, D. R., \& Pulvers, K, M. 2002. Hope in the workplace. In R. Giacolone \& C. Jurkiewicz (eds.), Handbook of workplace spirituality and organizational performance: 367-377. New York: Sharpe.

Adler, P. S., \& Kwon, S. 2002. Social capital: Prospects for a new concept. Academy of Management Review, 27: 17-40.

Ang, S., Van Dyne, L., \& Koh, C. 2006. Personality correlates of the four-factor model of cultural intelligence. Group \& Organization Management, 31: 100-123.

Antonovsky, A. 1979. Health, stress, and coping. San Francisco: Jossey-Bass.

Aspinwall, L., \& Staudinger, U. (eds.). 2003. A psychology of human strengths: Fundamental questions and future directions for a positive psychology. Washington, DC: American Psychological Association.

Avolio, B. J., Bass, B., \& Jung, D. 1999. Re-examining the components of transformational and transactional leadership using the multi factor leadership questionnaire. Journal of Occupational and Organizational Psychology, 72: 441-462.

Avolio, B. J., \& Luthans, F. 2006. The high impact leader: Moments matter in accelerating authentic leadership development. New York: McGraw-Hill.

Bagozzi, R. P. 2003. Positive and negative emotions in organizations. In K. S. Cameron, J. E. Dutton, \& R. E. Quinn (eds.), Positive organizational scholarship: 176-193. San Francisco: Berrett-Koehler.

Bakker, A. B., van der Zee, K. I., Lewig, K. A., \& Dollard, M. F. 2006. The relationship between the Big Five personality factors and burnout: A study among volunteer counselors. Journal of Social Psychology, 146(1): 31-50.

Bandura, A. 1986. Social foundations of thought and action: A social cognitive theory. Englewood Cliffs, NJ: Prentice Hall.

Bandura, A. 1997. Self-efficacy: The exercise of control. New York: Freeman.

Bandura, A. 2000. Cultivate self-efficacy for personal and organizational effectiveness. In E. Locke (Ed.), Handbook of principles of organizational behavior: 120-136. Oxford, UK: Blackwell.

Bandura, A. 2001. Social cognitive theory: An agentic perspective. Annual Review of Psychology, 52: 1-26. 
Bandura, A., \& Locke, E. 2003. Negative self-efficacy and goal effects revisited. Journal of Applied Psychology, 88: 87-99.

Barrick, M. R., \& Mount, M. K. 1991. The Big Five personality dimensions and job performance: A meta-analysis. Personnel Psychology, 44: 1-26

Best, R. G., Stapleton, L. M., \& Downey, R. G. 2005. Core self-evaluations and job burnout: The test of alternative models. Journal of Occupational Health Psychology, 10: 441-451.

Block, J., \& Kremen, A. M. 1996. IQ and ego-resiliency: Conceptual and empirical connections and separateness. Journal of Personality and Social Psychology, 70: 349-361.

Bonanno, G. A. 2004. Loss, trauma and human resilience: Have we underestimated the human capacity to thrive after extremely aversive events? American Psychologist, 59: 20-28.

Bonanno, G. A. 2005. Clarifying and extending the construct of adult resilience. American Psychologist, 60: 265-267.

Boyd, N. G., \& Vozikis, G. S. 1994. The influence of self-efficacy on the development of entrepreneurial intentions and actions. Entrepreneurship Theory and Practice, 18: 63-77.

Brief, A. P., \& Motowidlo, S. J. 1986. Prosocial organizational behaviors. Academy of Management Review, 11: 710-725.

Bryant, F. B., \& Cvengros, J. A. 2004. Distinguishing hope and optimism. Journal of Social and Clinical Psychology, 23: 273-302.

Buckingham, M., \& Clifton, D. 2001. Now, discover your strengths. New York: Free Press.

Buckingham, M., \& Coffman, C. 1999. First, break all the rules: What the world's greatest managers do differently. New York: Simon \& Schuster.

Cameron, K. S., Bright, D., \& Caza, A. 2004. Exploring the relationships between organizational virtuousness and performance. American Behavioral Scientist, 47: 766-790.

Cameron, K. S., \& Caza, A. 2004. Contributions to the discipline of positive organizational scholarship. American Behavioral Scientist, 47: 731-739.

Cameron, K. S., Dutton, J., \& Quinn, R. (eds.). 2003. Positive organizational scholarship. San Francisco: Berrett- Koehler.

Carifio, J., \& Rhodes, L. 2002. Construct validities and the empirical relationships between optimism, hope, self-efficacy, and locus of control. Work, 19: 125-136.

Carr, A. 2004. Positive psychology. New York: Brunner-Routledge.

Carver, C., \& Scheier, M. 2002. Optimism. In C. R. Snyder \& S. Lopez (eds.), Handbook of positive psychology: 231-243. Oxford, UK: Oxford University Press.

Chakravarthy, B. S. 1986. Measuring strategic performance. Strategic Management Journal, 7: 437-458.

Chandler, G. N., \& Jansen, E. 1997. Founder self-efficacy and venture performance: A longitudinal study. Academy of Management Proceedings: 98-102.

Chemers, M. M., Watson, C. B., \& May, S. T. 2000. Dispositional affect and leadership effectiveness: A comparison of self-esteem, optimism, and efficacy. Personality and Social Psychology Bulletin, 26: 267-277.

Chen, C. C., Greene, P. G., \& Crick, A. 1998. Does entrepreneurial self-efficacy distinguish entrepreneurs from managers? Journal of Business Venturing, 13: 295-316.

Chen, G., Gully, S. M., Whiteman, J. A., \& Kilcullen, R. N. 2000. Examination of relationships among trait-like individual differences, state-like individual differences, and learning performance. Journal of Applied Psychology, 85: 835-847.

Coleman, J. S. 1988. Social capital in the creation of human capital. American Journal of Sociology, 94: 95-120.

Compton, W. C. 2005. Introduction to positive psychology. Belmont, CA: Thompson Wadsworth.

Conley, J. J. 1984. The hierarchy of consistency: A review and model of longitudinal findings on adult individual differences in intelligence, personality, and self-opinion. Personality and Individual Differences, 5: 11-25.

Conner, D. 1993. Managing at the speed of change: How resilient managers succeed and prosper where others fail. New York: Villard.

Cooperrider, D., \& Srivastva, S. 1987. Appreciative inquiry in organizational life. Research in Organizational Change and Development, 1: 129-169.

Coutu, D. L. 2002. How resilience works. Harvard Business Review, 80(5): 46-55.

Cowan, P. A., Cowan, C. P., \& Schulz, M. S. 1996. Thinking about risk and resilience in families. In E. M. Hetherington \& E. A. Blechman (eds.), Stress, coping, and resiliency in children and families: 1-38. Mahwah, NJ: Lawrence Erlbaum.

Cozzarelli, C. 1993. Personality and self-efficacy as predictors of coping with abortion. Journal of Personality and Social Psychology, 65: 1224-1237. 
Curry, L. A., Snyder, C. R., Cook, D. I., Ruby, B. C., \& Rehm, M. 1997. The role of hope in student-athlete academic and sport achievement. Journal of Personality and Social Psychology, 73: 1257-1267.

Dess, G. G., \& Robinson, R. B., Jr. 1984. Measuring organizational performance in the absence of objective measures: The case of the privately held firm and conglomerate business unit. Strategic Management Journal, 5: 265-273.

Dudley, N. M., Orvis, K. A., Lebiecki, J. E., \& Cortina, J. M. 2006. A meta-analytic investigation of conscientiousness in the prediction of job performance: Examining the intercorrelations and the incremental validity of narrow traits. Journal of Applied Psychology, 91: 40-57.

Egeland, B., Carlson, E., \& Sroufe, L. A. 1993. Resilience as a process. Development and Psychopathology, 5: 517-528.

Erez, A., \& Judge, T. A. 2001. Relationship of core self-evaluations to goal setting, motivation, and performance. Journal of Applied Psychology, 86: 1270-1279.

Fineman, S. 2006. On being positive: Concerns and counterpoints. Academy of Management Review, 31: 270-291.

Fredrickson, B. L. 2001. The role of positive emotions in positive psychology: The broaden-and-build theory of positive emotions. American Psychologist, 56: 218-226.

Fredrickson, B. L. 2003a. Positive emotions and upward spirals in organizations. In K. S. Cameron, J. E. Dutton, \& R. E. Quinn (eds.), Positive organizational scholarship: 163-175. San Francisco: Berrett-Koehler.

Fredrickson, B. L. 2003b. The value of positive emotions. American Scientist, 91: 330-335.

Friedman, T. L. 2005. The world is flat. New York: Farrar, Straus and Giroux.

Gardner, W. L., Avolio, B. J., Luthans, F., May, D. R., \& Walumbwa, F. O. 2005. "Can you see the real me?" A self-based model of authentic leader and follower development. Leadership Quarterly, 16: 343-372.

George, J. M. 1991. State or trait: Effects of positive mood on prosocial behaviors at work. Journal of Applied Psychology, 76: 299-307.

Giacalone, R. A., Jurkiewicz, C., \& Dunn, C. (eds.). 2005. Positive psychology in business ethics and corporate social responsibility. Greenwich, CT: Information Age.

Harland, L., Harrison, W., Jones, J., \& Reiter-Palmon, R. 2005. Leadership behaviors and subordinate resilience. Journal of Leadership and Organizational Studies, 11: 2-14.

Harter, J., Schmidt, F., \& Hayes, T. 2002. Business-unit-level relationship between employee satisfaction, employee engagement, and business outcomes: A meta-analysis. Journal of Applied Psychology, 87: 268-279.

Harter, J., Schmidt, F., \& Keyes, C. 2003. Well-being in the workplace and its relationship to business outcomes: A review of the Gallup studies. In C. Keyes \& J. Haidt (eds.), Flourishing: Positive psychology and the life well-lived: 205-224. Washington, DC: American Psychological Association.

Hobfoll, S. 2002. Social and psychological resources and adaptation. Review of General Psychology, 6: 307-324.

Huey, S. J., Jr., \& Weisz, J. R. 1997. Ego control, ego resiliency, and the five-factor model as predictors of behavioral and emotional problems in clinic-referred children and adolescents. Journal of Abnormal Psychology, 106: 404-415.

Hunter, A. J., \& Chandler, G. E. 1999. Adolescent resilience. Image: Journal of Nursing Scholarship, 31: 243-247.

Hunter, J. E., \& Hunter, R. R. 1984. Validity and utility of alternate predictors of job performance. Psychological Bulletin, 96: 72-98.

Huselid, M. A. 1995. The impact of human resource management practices on turnover, productivity, and corporate financial performance. Academy of Management Journal, 38: 635-672.

Ilies, R., Scott, B. A., \& Judge, T. A. 2006. The interactive effects of personal traits and experienced states on intraindividual patterns of citizenship behavior. Academy of Management Journal, 49: 561-575.

Jensen, S. M., \& Luthans, F. 2002. The impact of hope in the entrepreneurial process: Exploratory research findings. Decision Sciences Institute Conference Proceedings, San Diego, CA.

Jensen, S. M., \& Luthans, F. 2006. Relationship between entrepreneurs' psychological capital and their authentic leadership. Journal of Managerial Issues, 18: 254-273.

Johnson, K., Bryant, D., Collins, D., Noe, T., Strader, T., \& Berbaum, M. 1998. Preventing and reducing alcohol and other drug use among high-risk youths by increasing family resilience. Social Work, 43 : 297-308. 
Judge, T. A., \& Bono, J. E. 2001. Relationship of core self-evaluations traits - self-esteem, generalized self-efficacy, locus of control, and emotional stability - with job satisfaction and job performance: A meta-analysis. Journal of Applied Psychology, 86: 80-92.

Judge, T. A., Bono, J. E., Erez, A., \& Locke, E. A. 2005. Core self-evaluations and job and life satisfaction: The role of self-concordance and goal attainment. Journal of Applied Psychology, 90: 257-268.

Judge, T. A., Bono, J. E., \& Locke, E. A. 2000. Personality and job satisfaction: The mediating role of job characteristics. Journal of Applied Psychology, 85: 237-249.

Judge, T. A., Colbert, J. E., \& Ilies, R. 2004. Intelligence and leadership: A quantitative review and test of theoretical propositions. Journal of Applied Psychology, 89: 542-552.

Judge, T. A., Locke, E. A., Durham, C. C., \& Kluger, A. N. 1998. Dispositional effects on job and life satisfaction: The role of core evaluations. Journal of Applied Psychology, 83: 17-34.

Judge, T. A., Van Vianen, A. E. M., \& De Pater, I. E. 2004. Emotional stability, core self-evaluations, and job outcomes: A review of the evidence and an agenda for future research. Human Performance, 17: 325-346.

Kanov, J. M., Maitlis, S., Worline, M. C., Dutton, J. E., Frost, P. J., \& Liltus, J. M. 2004. Compassion in organizational life. American Behavioral Scientist, 47: 808-827.

Kanter, R. M. 2004. Confidence. New York: Crown.

Keyes, C., \& Haidt, J. (eds.). 2003. Flourishing: Positive psychology and the life well-lived. Washington, DC: American Psychological Association.

Kilduff, M. 2006. Editor's comments: Publishing theory. Academy of Management Review, 31: 252-255.

Kirby, L., \& Fraser, M. 1997. Risk and resilience in childhood. In M. Fraser (Ed.), Risk and resilience in childhood: 10-33. Washington, DC: NASW Press.

Klein, K. J., \& Kozlowski, S. W. (eds.). 2000. Multilevel theory, research, and methods in organizations. San Francisco: Jossey-Bass.

Kobasa, S. 1979. Stressful life events, personality and health: An inquiry into hardiness. Journal of Personality and Social Psychology, 37: 1-11.

Kwon, P. 2000. Hope and dysphoria: The moderating role of defense mechanisms. Journal of Personality, 68: 199-223.

Lam, S., Chen, X., \& Schaubroeck, J. 2002. Participative decision making and employee performance in different cultures: The moderating effects of allocentrism/idiocentrism and efficacy. Academy of Management Journal, 45: 905-914.

LaMarch, J. 1997. The resilient worker: Employees who can cope with change. Hospital Material Management Quarterly, 19(2): 54-58.

Larson, M., \& Luthans, F. 2006. The potential added value of psychological capital in predicting work attitudes. Journal of Leadership and Organization Studies, 13: 44-61.

Law, K. S., Wong, C., \& Mobley, W. H. 1998. Toward a taxonomy of multidimensional constructs. Academy of Management Review, 23: 741-755.

LeBreton, J. M., James, L. R., \& Lindell, M. K. 2005. Recent issues regarding rWG, r*WG, rWG(J), $r^{*} \mathrm{WG}(\mathrm{J})$. Organizational Research Methods, 8: 128-138.

Lee, K., \& Allen, N. J. 2002. Organizational citizenship behavior and workplace deviance: The role of affect and cognitions. Journal of Applied Psychology, 18: 131-142.

LePine, J. A., Erez, A., \& Johnson, D. E. 2002. The nature and dimensionality of organizational citizenship behavior: A critical review and meta-analysis. Journal of Applied Psychology, 87: 52-65.

Linley, P., \& Joseph, S. (eds.). 2004. Positive psychology in practice. Hoboken, NJ: John Wiley.

Lopez, S., \& Snyder, C. R. (eds.). 2003. Positive psychological assessment: A handbook of models and measures. Washington, DC: American Psychological Association.

Luthans, F. 2002a. The need for and meaning of positive organizational behavior. Journal of Organizational Behavior, 23: 695-706.

Luthans, F. 2002b. Positive organizational behavior: Developing and managing psychological strengths. Academy of Management Executive, 16(1): 57-72.

Luthans, F. 2003. Positive organizational behavior (POB): Implications for leadership and HR development and motivation. In R. M. Steers, L. W. Porter, \& G. A. Begley (eds.), Motivation and leadership at work: 187-195. New York: McGraw-Hill/Irwin.

Luthans, F., Avey, J. B., \& Avolio, B. J. 2007. The impact of psychological capital interventions on performance outcomes. Working paper, Gallup Leadership Institute, University of Nebraska.

Luthans, F., Avey, J. B., Avolio, B. J., Norman, S. M., \& Combs, G. J. 2006. Psychological capital development: Toward a micro-intervention. Journal of Organizational Behavior, 27: 387-393. 
Luthans, F., \& Avolio, B. 2003. Authentic leadership: A positive development approach. In K. S. Cameron, J. E. Dutton, \& R. E. Quinn (eds.), Positive organizational scholarship: 241-258. San Francisco: Berrett-Koehler.

Luthans, F., Avolio, B., Avey, J., \& Norman, S. (in press). Positive psychological capital: Measurement and relationship with performance and satisfaction. Personnel Psychology.

Luthans, F., Avolio, B. J., Walumbwa, F. O., \& Li, W. 2005. The psychological capital of Chinese workers: Exploring the relationship with performance. Management and Organization Review, 1: 247-269.

Luthans, F., \& Ibrayeva, E. S. 2006. Entrepreneurial self-efficacy in Central Asian transition economies: Quantitative and qualitative analyses. Journal of International Business Studies, 37: 92-110.

Luthans, F., \& Jensen, S. M. 2002. Hope: A new positive strength for human resource development. Human Resource Development Review, 1: 304-322.

Luthans, F., Luthans, K., Hodgetts, R., \& Luthans, B. 2001. Positive approach to leadership (PAL): Implications for today's organizations. Journal of Leadership Studies, 8(2): 3-20.

Luthans, F., Luthans, K., \& Luthans, B. 2004. Positive psychological capital: Going beyond human and social capital. Business Horizons, 47(1): 45-50.

Luthans, F., Norman, S. M., \& Hughes, L. 2006. Authentic leadership. In R. Burke \& C. Cooper (eds.), Inspiring leaders: 84-104. London: Routledge, Taylor \& Francis.

Luthans, F., Van Wyk, R., \& Walumbwa, F. O. 2004. Recognition and development of hope for South African organizational leaders. Leadership \& Organization Development Journal, 25: 512-527.

Luthans, F., Vogelgesang, G. R., \& Lester, P. B. 2006. Developing the psychological capital of resiliency. Human Resource Development Review, 5(1): 25-44.

Luthans, F., \& Youssef, C. M. 2004. Human, social, and now positive psychological capital management: Investing in people for competitive advantage. Organizational Dynamics, 33: 143-160.

Luthans, F., Youssef, C. M., \& Avolio, B. J. 2007a. Psychological capital: Developing the human competitive edge. Oxford, UK: Oxford University Press.

Luthans, F., Youssef, C. M., \& Avolio, B. J. 2007b. Psychological capital: Investing and developing positive organizational behavior. In D. Nelson \& C. L. Cooper (eds.), Positive organizational behavior: Accentuating the positive at work: 9-24. Thousand Oaks, CA: Sage.

Luthans, F., Zhu, W., \& Avolio, B. J. 2006. The impact of efficacy on work attitudes across cultures. Journal of World Business, 41: 121-132.

Maddux, J. E. 2002. Self-efficacy: The power of believing you can. In C. R. Snyder \& S. Lopez (eds.), Handbook of positive psychology: 257-276. Oxford, UK: Oxford University Press.

Magaletta, P. R., \& Oliver, J. M. 1999. The hope construct, will, and ways: Their relations with efficacy, optimism, and general well-being. Journal of Clinical Psychology, 55: 539-551.

Masten, A. S. 2001. Ordinary magic: Resilience process in development. American Psychologist, 56: 227-239.

Masten, A. S., \& Reed, M. J. 2002. Resilience in development. In C. R. Snyder \& S. Lopez (eds.), Handbook of positive psychology: 74-88. Oxford, UK: Oxford University Press.

Maurer, T. J., \& Pierce, H. R. 1998. A comparison of Likert scale and traditional measures of self-efficacy. Journal of Applied Psychology, 83: 324-329.

May, D., Chan, A., Hodges, T., \& Avolio, B. 2003. Developing the moral component of authentic leadership. Organizational Dynamics, 32: 247-260.

Miceli, M., \& Near, J. 2005. Whistle-blowing and positive psychology. In R. A. Giacalone, C. Jurkiewicz, \& C. Dunn (eds.), Positive psychology in business ethics and corporate social responsibility: 85-102. Greenwich, CT: Information Age.

Michie, S., \& Gooty, J. 2005. Values, emotions, and authenticity: Will the real leader please stand up? Leadership Quarterly, 16: 441-457.

Moorman, R. H., Blakely, G. L., \& Niehoff, B. P. 1998. Does perceived organizational support mediate the relationship between procedural justice and organizational citizenship behavior? Academy of Management Journal, 41: 351-357.

Mount, M. K., \& Barrick, M. R. 1995. The Big Five personality dimensions: Implications for research and practice in human resources management. Research in Personnel and Human Resource Management, 13: 152-200.

Neck, C. P., Neck, H. M., Manz, C. C., \& Godwin, J. 1999. "I think I can; I think I can”: A self leadership perspective toward enhancing entrepreneurial thought patterns, self-efficacy, and performance. Journal of Management Psychology, 14: 477-501.

Nelson, D., \& Cooper, C. L. (eds.). 2007. Positive organizational behavior: Accentuating the positive at work. Thousand Oaks, CA: Sage. 
Nilsson, J., Schmidt, C., \& Meek, W. 2002. Reliability generalization: An examination of the career decision-making self-efficacy scale. Educational and Psychological Measurement, 62: 647-658.

Norman, S. E., Avolio, B. J., \& Luthans, F. 2007. Trusting the leader: The role of transparency and positivity. Working paper, Gallup Leadership Institute, University of Nebraska.

Onwuegbuzie, A. J., \& Snyder, C. R. 2000. Relations between hope and graduate students' coping strategies for studying and examination taking. Psychological Reports, 86: 803-806.

Organ, D. W. 1988. Organizational citizenship behavior: The good soldier syndrome. Lexington, MA: Lexington Books.

Organ, D. W., \& Ryan, K. 1995. A meta-analytic review of attitudinal and dispositional predictors of organizational citizenship behavior. Personnel Psychology, 48: 775-802.

Ozer, D. J., \& Benet-Martínez, V. 2006. Personality and the prediction of consequential outcomes. Annual Review of Psychology, 57: 401-421.

Parker, S. 1998. Enhancing role breadth self-efficacy: The roles of job enrichment and other organizational interventions. Journal of Applied Psychology, 6: 835-852.

Peeters, M. A., Rutte, C. G., van Tuijl, H. F., \& Reymen, I. M. 2006. The Big Five personality traits and individual satisfaction with the team. Small Group Research, 37: 187-211.

Peterson, C. 1999. Personal control and well-being. In D. Kahneman, E. Diener, \& N. Schwarz (eds.), Well-being: The foundations of hedonic psychology: 288-301. New York: Russell Sage.

Peterson, C. 2000. The future of optimism. American Psychologist, 55: 44-55.

Peterson, C. 2006. A primer in positive psychology. New York: Oxford University Press.

Peterson, C., \& Barrett, L. 1987. Explanatory style and academic performance among university freshmen. Journal of Personality and Social Psychology, 53: 603-607.

Peterson, C., \& Chang, E. 2002. Optimism and flourishing. In C. Keyes \& J. Haidt (eds.), Flourishing: Positive psychology and the life well-lived: 55-79. Washington, DC: American Psychological Association.

Peterson, C., \& Seligman, M. 1984. Causal explanations as a risk factor for depression: Theory and evidence. Psychological Review, 91: 347-374.

Peterson, C., \& Seligman, M. 2004. Character strengths and virtues: A handbook and classification. New York: Oxford University Press.

Peterson, C., Seligman, M., \& Vaillant, G. 1988. Pessimistic explanatory style is a risk factor for physical illness: A thirty-five year longitudinal study. Journal of Personality and Social Psychology, 55: 23-27.

Peterson, C., \& Steen, T. 2002. Optimistic explanatory style. In C. R. Snyder \& S. Lopez (eds.), Handbook of positive psychology: 244-256. Oxford, UK: Oxford University Press.

Peterson, S. J., \& Luthans, F. 2003. The positive impact and development of hopeful leaders. Leadership and Organization Development Journal, 24: 26-31.

Pfeffer, J. 1998. The human equation. Boston: Harvard Business School Press.

Podsakoff, P. M., MacKenzie, S. C., Lee, J., \& Podsakoff, N. P. 2003. Common method biases in behavioral research: A critical review of the literature and recommended remedies. Journal of Applied Psychology, 88: 879-903.

Podsakoff, P. M., MacKenzie, S. C., Moorman, R. H., \& Fetter, R. 1990. Transformational leader behaviors and their effects on followers' trust in leader, satisfaction, and organizational citizenship behaviors. Leadership Quarterly, 1: 107-142.

Prola, M., \& Stern, D. 1984. Optimism about college life and academic performance in college. Psychological Reports, 55: 347-350.

Quick, J. C., \& Quick, J. D. 2004. Healthy, happy, productive work: A leadership challenge. Organizational Dynamics, 33: 329-337.

Ramakrishna, H. 2002. The moderating role of updating climate perceptions in the relationship between goal orientation, self-efficacy, and job performance. Human Performance, 15: 275-297.

Range, L., \& Pentin, S. 1994. Hope, hopelessness and suicidality in college students. Psychological Reports, 75: 456-458.

Reivich, K., \& Shatte, A. 2002. The resilience factor: 7 essential skills for overcoming life's inevitable obstacles. New York: Random House.

Richardson, G. 2002. The metatheory of resilience and resiliency. Journal of Clinical Psychology, 58: 307-321.

Rini, C. K., Dunkel-Schetter, C., Wadhwa, P. D., \& Sandman, C. A. 1999. Psychological adaptation and birth outcomes: The role of personal resources, stress, and socio-cultural context in pregnancy. Health Psychology, 18: 333-345. 
Roberts, L. M. 2006. Shifting the lens on organizational life: The added value of positive scholarship. Academy of Management Review, 31: 292-305.

Ryff, C., \& Singer, B. 2003. Flourishing under fire: Resilience as a prototype of challenged thriving. In C. Keyes \& J. Haidt (eds.), Flourishing: Positive psychology and the life well-lived: 15-36. Washington, DC: American Psychological Association.

Sandau-Beckler, P., Devall, E., \& de la Rosa, I. 2002. Strengthening family resilience: Prevention and treatment for high-risk substance-affected families. Journal of Individual Psychology, 58: 305-327.

Scheier, M., \& Carver, C. 1985. Optimism, coping, and health: Assessment and implications of generalized outcome expectancies. Health Psychology, 4: 219-247.

Scheier, M., \& Carver, C. 1987. Dispositional optimism and physical well-being: The influence of generalized outcome expectancies on health. Journal of Personality, 55: 169-210.

Scheier, M., \& Carver, C. 1992. Effects of optimism on psychological and physical well-being: Theoretical overview and empirical update. Cognitive Therapy and Research, 16: 201-228.

Scheier, M., Matthews, K., Owen, J., Magovern, G., Lefebvre, R. Abbott, R., \& Carver, C. 1989. Dispositional optimism and recovery from coronary artery bypass surgery: The beneficial effects of physical and psychological well-being. Journal of Personality and Social Psychology, 57: 1024-1040.

Schmidt, F. L., \& Hunter, J. E. 2000. Select on intelligence. In E. Locke (Ed.), The Blackwell handbook of principles of organizational behavior: 3-14. Oxford, UK: Blackwell.

Schmidt, F. L., Hunter, J. E., \& Pearlman, K. 1981. Task differences and validity of aptitude tests in selection: A red herring. Journal of Applied Psychology, 66: 165-185.

Schneider, S. L. 2001. In search of realistic optimism. American Psychologist, 56: 250-263.

Schulman, P. 1999. Applying learned optimism to increase sales productivity. Journal of Personal Selling and Sales Management, 19: 31-37.

Scioli, A., Chamberlin, C., Samor, C. M., LaPointe, A. B., Campbell, T. L., MacLeod, A. R., \& McLenon, J. A. 1997. A prospective study of hope, optimism, and health. Psychological Reports, 81: 723-733.

Seligman, M. E. P. 1998. Learned optimism. New York: Pocket Books.

Seligman, M. E. P. 2002. Authentic happiness. New York: Free Press. Seligman, M. E. P., \& Csikszentmihalyi, M. 2000. Positive psychology. American Psychologist, 55: 5-14.

Seligman, M. E. P., \& Schulman, P. 1986. Explanatory style as a predictor of productivity and quitting among life insurance sales agents. Journal of Personality and Social Psychology, 50: 832-838.

Shamir, B., \& Eilam, G. 2005. What's your story? A life-stories approach to authentic leadership development. Leadership Quarterly, 16: 395-417.

Smith, C., \& Carlson, B. 1997. Stress, coping, and resilience in children and youth. Social Service Review, 71: 231-256.

Snyder, C. R. 1993. Hope for the journey. In A. P. Turnbull, J. M. Patterson, S. K. Behr, D. L. Murphy, J. G. Marquis, \& M. J. Blue-Banning (eds.), Cognitive coping, families, and disability: 271-286. Baltimore: Paul H. Brooks.

Snyder, C. R. 1994. Hope and optimism. Encyclopedia of human behavior, vol. 2: 535-542. San Diego, CA: Academic Press.

Snyder, C. R. 1995a. Conceptualizing, measuring, and nurturing hope. Journal of Counseling and Development, 73: 355-360.

Snyder, C. R. 1995b. Managing for high hope. $R$ E D Innovator, 4(6): 6-7.

Snyder, C. R. 2000. Handbook of hope. San Diego, CA: Academic Press.

Snyder, C. R. 2002. Hope theory: Rainbows in the mind. Psychological Inquiry, 13: 249-275.

Snyder, C. R., Harris, C., Anderson, J. R., Holleran, S. A., Irving, L. M., Sigmon, S. T., Yoshinobu, L., Gibb, J., Langelle, C., \& Harney, P. 1991. The will and the ways: Development and validation of an individual-differences measure of hope. Journal of Personality and Social Psychology, 60: 570-585.

Snyder, C. R., Ilardi, S., Michael, S. T., \& Cheavens, J. 2000. Hope theory: Updating a common process for psychological change. In C. R. Snyder \& R. E. Ingram (eds.), Handbook of psychological change: Psychotherapy processes and practices for the 21st century: 128-153. New York: John Wiley.

Snyder, C. R., Irving, L., \& Anderson, J. 1991. Hope and health: Measuring the will and the ways. In C. R. Snyder \& D. R. Forsyth (eds.), Handbook of social and clinical psychology: 285-305. Elmsford, NY: Pergamon.

Snyder, C. R., \& Lopez, S. (eds.). 2002. Handbook of positive psychology. Oxford, UK: Oxford University Press.

Snyder, C. R., Rand, K. L., \& Sigmon, D. R. 2002. Hope theory. In C. R. Snyder \& S. Lopez (eds.), Handbook of positive psychology: 257-276. Oxford, UK: Oxford University Press. 
Snyder, C. R., Sympson, S. C., Ybasco, F. C., Borders, T. F., Babyak, M. A., \& Higgins, R. L. 1996. Development and validation of the state hope scale. Journal of Personality and Social Psychology, 70: 321-335.

Snyder, C. R., Tran, T., Schroeder, L. L., Pulvers, K. M., Adam, V., III, \& Laub, L. 2000. Teaching the hope recipe: Setting goals, finding pathways to those goals, and getting motivated. National Educational Service, Summer: 46-50.

Sparrowe, R. T. 2005. Authentic leadership and the narrative self. Leadership Quarterly, 16: 419-439.

Spreitzer, G. M. 1995. Psychological empowerment in the workplace: Dimensions, measurement, and validation. Academy of Management Journal, 38: 1442-1465.

Spreitzer, G. M., \& Sonenshein, S. 2004. Toward the construct definition of positive deviance. American Behavioral Scientist, 47: 828-847.

Stajkovic, A. D. 2006. Development of a core confidence-higher order construct. Journal of Applied Psychology, 91: 1208-1224.

Stajkovic, A. D., \& Luthans, F. 1998a. Self-efficacy and work-related performance: A meta-analysis. Psychological Bulletin, 124: 240-261.

Stajkovic, A. D., \& Luthans, F. 1998b. Social cognitive theory and self-efficacy: Going beyond traditional motivational and behavioral approaches. Organizational Dynamics, 26: 62-74.

Stewart, G. L., \& Nandkeolyar, A. K. 2006. Adaptation and intraindividual variation in sales outcomes: Exploring the interactive effects of personality and environmental opportunity. Personnel Psychology, 59: 307-332.

Stewart, M., Reid, G., \& Mangham, C. 1997. Fostering children's resilience. Journal of Pediatric Nursing, 12: 21-31.

Sutcliffe, K. M., \& Vogus, T. 2003. Organizing for resilience. In K. S. Cameron, J. E. Dutton, \& R. E. Quinn (eds.), Positive organizational scholarship: 94-110. San Francisco: Berrett-Koehler.

Tedeschi, R., Park, C., \& Calhoun L. (eds.). 1998. Posttraumatic growth: Positive changes in the aftermath of crisis. Mahwah, NJ: Lawrence Erlbaum.

Thatchenkery, T., \& Metzker, C. 2006. Appreciative intelligence. San Francisco: Berrett-Koehler.

Thoits, P. 1994. Stressors and problem solving: The individual as a psychological activist. Journal of Health and Social Behavior, 35: 143-160.

Tierney, P., \& Farmer, S. 2002. Creative self-efficacy: Its potential antecedents and relationship to creative performance. Academy of Management Journal, 45: 1137-1148.

Vancouver, J., Thompson, C., Tischner, E., \& Putka, D. 2002. Two studies examining the negative effect of self-efficacy on performance. Journal of Applied Psychology, 87: 506-516.

Vancouver, J., Thompson, C., \& Williams, A. 2001. The changing signs in the relationship between self-efficacy, personal goals, and performance. Journal of Applied Psychology, 86: 605-620.

Veninga, R. L. 2000. Managing hope in the workplace: Five simple strategies can help transform organizations. Health Progress, 81: 22-24.

Vickers, M. H., \& Kouzmin, A. 2001. Resilience in organizational actors and rearticulating voice. Public Management Review, 3(1): 95-119.

Wagner, R., \& Harter, J. K. 2006. 12: The elements of great managing. New York: Gallup Press.

Wagnild, G., \& Young, H. 1993. Development and psychometric evaluation of the resiliency scale. Journal of Nursing Measurement, 1(2): 165-178.

Waite, P., \& Richardson, G. 2004. Determining the efficacy of resiliency training in the work site. Journal of Allied Health, 33: 178-183.

Waterman, R. H., Waterman, J. A., \& Collard, B. A. 1994. Toward a career-resilient workforce. Harvard Business Review, 72(4): 87-95.

Weick, K. E. 1993. The collapse of sense-making in organizations: The Mann Gulch disaster. Administrative Science Quarterly, 38: 628-652.

Wolin, S., \& Wolin, S. 2006. Project resilience. URL (August 1, 2006): http://www.projectresilience.com

Wooten, L. P., \& Crane, P. 2004. Generating dynamic capabilities through a humanistic work ideology. American Behavioral Scientist, 47: 848-866.

Worline, M., \& Quinn, R. 2003. Courageous principled action. In K. S. Cameron, J. E. Dutton, \& R. E. Quinn (eds.), Positive organizational scholarship: 138-157. San Francisco: Berrett-Koehler.

Wright, R. M., \& Snell, S. A. 1999. Social capital and strategic HRM: It's who you know. Human Resource Planning, 22: 62-65.

Wright, T. A. 1997. Time revisited in organizational behavior. Journal of Organizational Behavior, 18: 201-204. 
Wright, T. A. 2003. Positive organizational behavior: An idea whose time has truly come. Journal of Organizational Behavior, 24: 437-442.

Wright, T. A. 2005. The role of "happiness" in organizational research: Past, present and future directions. In P. L. Perrewe \& D. C. Ganster (eds.), Research in occupational stress and well-being, vol. 4: 221-264. Amsterdam: JAI.

Wright, T. A. 2006. To be or not to be (happy): The role of employee well-being. Academy of Management Perspectives, 20: 118-120.

Wright, T. A. 2007. A look at two methodological challenges for scholars interested in positive organizational behavior. In D. Nelson \& C. L. Cooper (eds.), Positive organizational behavior: Accentuating the positive at work: 177-190. Thousand Oaks, CA: Sage.

Wright, T. A., \& Bonett, D. G. in press. Job satisfaction and psychological well-being as non-additive predictors of workplace turnover. Journal of Management.

Wright, T. A., \& Cropanzano, R. 2000. Psychological well-being and job satisfaction as predictors of job performance. Journal of Occupational Health Psychology, 5: 84-94.

Wright, T. A., \& Cropanzano, R. 2004. The role of psychological well-being in job performance. Organizational Dynamics, 33: 338-351.

Wright, T. A., Cropanzano, R., \& Bonett, D. G. in press. The moderating role of employee positive well-being on the relation between job satisfaction and job performance. Journal of Occupational Health Psychology.

Wunderley, L. J., Reddy, W. P., \& Dember, W. N. 1998. Optimism and pessimism in business leaders. Journal of Applied Social Psychology, 28: 751-760.

Youssef, C. M., \& Luthans, F. 2003. Immigrant psychological capital: Contribution to the war for talent and competitive advantage. Singapore Nanyang Business Review, 2(2): 1-14.

Youssef, C. M., \& Luthans, F. 2005a. A positive organizational behavior approach to ethical performance. In R. A. Giacalone, C. Jurkiewicz, \& C. Dunn (eds.). Positive psychology in business ethics and corporate social responsibility: 1-22. Greenwich, CT: Information Age.

Youssef, C. M., \& Luthans, F. 2005b. Resiliency development of organizations, leaders and employees: Multi-level theory building for sustained performance. In W. Gardner, B. Avolio, \& F. Walumbwa (eds.), Authentic leadership theory and practice: Origins, effects and development: 303-343. Oxford, UK: Elsevier.

Youssef, C. M., \& Luthans, F. 2006. Time for positivity in the Middle East: Developing hopeful Egyptian organizational leaders. In W. Mobley \& E. Weldon (eds.), Advances in global leadership, vol. 4: 283-297. Oxford, UK: Elsevier Science/JAI.

Youssef, C. M., \& Luthans, F. (in press). Positive organizational behavior in the workplace: The impact of hope, optimism, and resilience. Journal of Management.

Zhao, H., \& Seibert, S. E. 2006. The big five personality dimensions and entrepreneurial status: A meta-analytical review. Journal of Applied Psychology, 91: 259-271.

Zunz, S. 1998. Resiliency and burnout: Protective factors for human service managers. Administration in Social Work, 22(3): 39-54.

Fred Luthans is University and Holmes Distinguished Professor of Management at the University of Nebraska. He received his $\mathrm{PhD}$ from the University of Iowa. His research interests include psychological capital, authentic leadership development, and international organizational behavior topics.

Carolyn M. Youssef is a management professor at Bellevue University. She received her PhD from the University of Nebraska, Lincoln. Her research interests include positive organizational behavior and psychological capital. 